\title{
Evaluation of some growth promoting bacterial strains exist on Eggplant root Solanumm elongena $\mathbf{L}$. against Rhizoctonia solani Rhizoctonia solani تقييم السلالات البكتيرية المحفزة لنمو النبات ضد الفطر Solanumm elongena L. على نبات الباذنجان
}

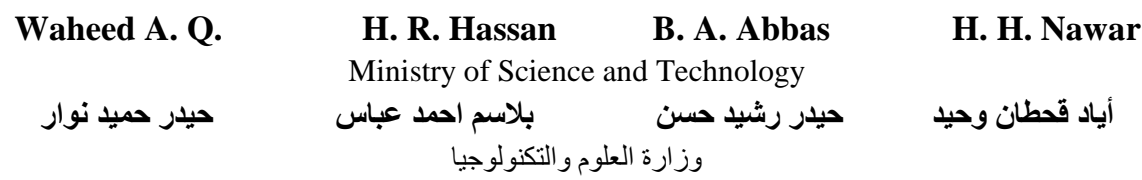

\begin{abstract}
In this study, six plant growth promoting bacterial strains were tested against eggplant root rot disease caused by Rhizoctonia solani. The bacterial strains were evaluated for their ability to promote growth and control $R$. solani in eggplant under greenhouse conditions. The results of antagonistic activity of the bacterial strains against $R$. solani showed that the tested strains controlled the radial growth of $R$. solani ranging from 24.66 to $40.33 \mathrm{~mm}$, of these, Bacillus subtilis was the most promising strains which recorded $24.66 \mathrm{~mm}$. Results of the treatment eggplant seeds with the bacterial suspension of the six strains showed that all tested strains significantly increased the percentage of seeds germination as compared to control treatment, $B$. subtilis strain was the best which recorded $92.16 \%$ as compared to $69.56 \%$ for control treatment. The greenhouse experiment revealed that the plants treated with $B$. subtilis recorded maximum (Shoot length, root length, fresh and dry weight of plant, rate of fruits weight, plant productivity). All these parameters were increased by $93.83 \mathrm{~cm}, 26.50 \mathrm{~cm}, 589.30 \mathrm{~g} /$ plant, 163.03 g/ plant, $101.63 \mathrm{~g}, 1180 \mathrm{~g} /$ plant respectively, also the results showed $B$. subtilis significantly decreased disease incidence and severity of eggplant infected by $R$. solani which recorded 34.06, 0.23 respectively as compared to both positive without pathogen and negative with pathogen control treatment $(4.4 \%, 77.33),(0.07 \%, 0.71)$ respectively.
\end{abstract}

Key words: eggplant, promoting bacterial

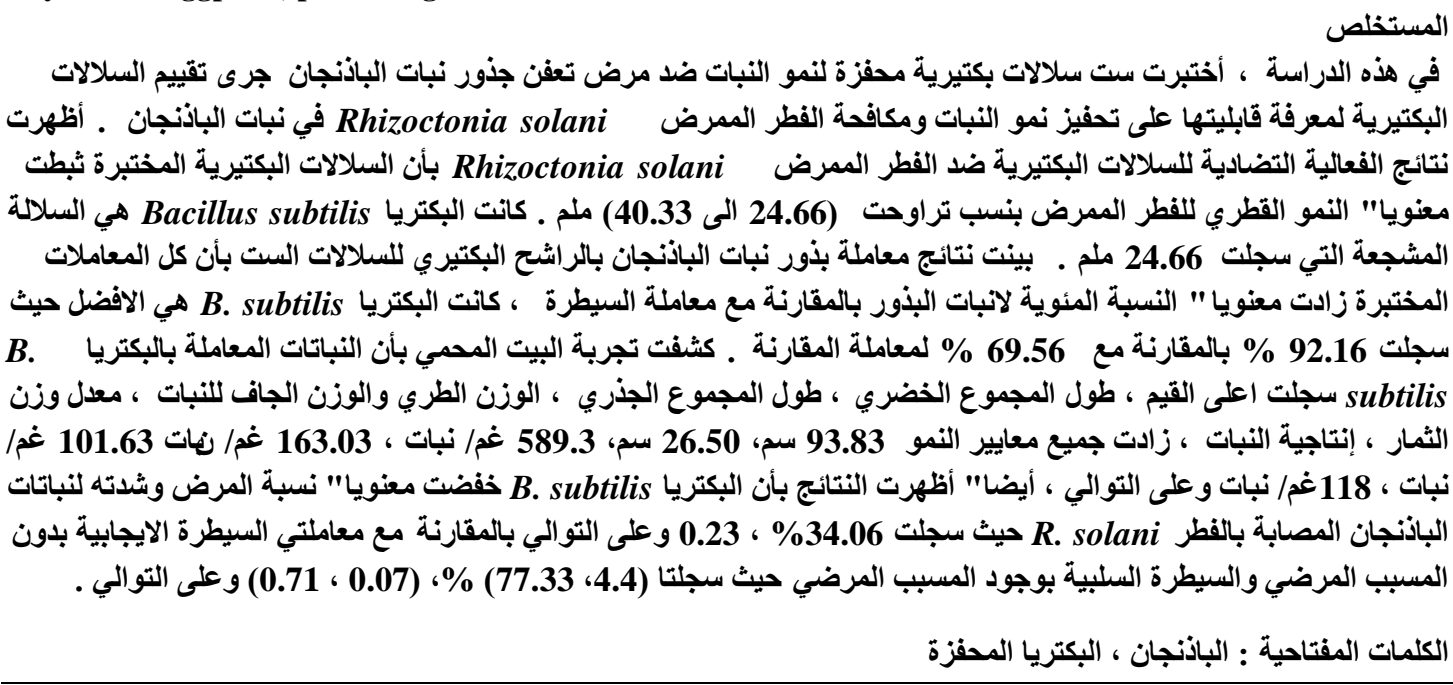

\section{Introduction}

Eggplant Solanumm elongena $\mathrm{L}$. is one of the most popular and important commercial vegetable crops grow throughout the world. Eggplant is affected by a number of fungi diseases causing substantial losses in yields including root rot and vascular wilt and damping-off diseases, which inflict heavy losses in its production [1]. Microorganisms such as bacteria are important to control phytopathogenic fungi and to promote the circulation of plant nutrients and reduce the need of chemical fertilizers, which are costly and create environmental problems for warranting high yield and quality [2]. Hence, there has recently been a resurgence of interest in environmentally friendly, sustainable and organic agricultural practices [3]. The use of beneficial microorganisms is positively known to affect on disease and plant growth $[4,5]$. Number of inoculated bacterial species mostly associated with the plant 
rhizosphere have been tested and found to be beneficial for plant growth, yield and crop quality [2]. They have been called plant growth promoting bacteria (PGPB), including the strains in the genera Azotobacter, Bacillus, Azosperilium, Rhizobium, Pseudomonas [6,7].These bacteria were previously reported as plant growth promoting bacteria and had potential biocontrol agents against a wide range of fungal pathogens $[8,9,10]$.

The objective of this study was to determine the effects of inoculation bacteria (Bacillus subtilis, Bacillus pumilus, Pseudomonas fluorescence, Azotobactre chroococcum1, Azotobactre chroococcum2, Bacillus sp.) in control root rot disease caused by Rhizoctonia solani and on yield and growth of eggplant vegetable crop in greenhouse conditions.

\section{Materials and methods}

\section{Bacterial strains and culture conditions}

Strains of plant growth promoting bacteria, Bacillus subtilis, Bacillus pumilus, Pseudomonas fluorescence were obtained from Organic Culture Center/ Ministry of Agriculture, whereas, bacterial strains, Azotobactre chroococcum1, Bacillus sp., Azotobacter chroococcum2 were isolated from bean, okra rhizosphere and garden soil Table (1), identified according to characteristic features of colony and bacterial cells. Bacterial strains were grown on Nutrient Agar (Difco Laboratories, USA) for routine use; a single colony was transferred to $250 \mathrm{ml}$ flasks containing Nutrient Broth and grown aerobically in flasks on a rotations shaker $95 \mathrm{rpm}$ for $48 \mathrm{hr}$ at $28^{\circ} \mathrm{C}$. The bacterial suspension was then diluted in sterile distilled water to a final concentration of $10^{8} \mathrm{CFU} / \mathrm{ml}$, and the resulting suspensions were used to treat seeds and seedlings eggplant plants.

Table (1): Source of Bacterial Isolates used in this study

\begin{tabular}{|c|c|c|}
\hline Bacterial isolates & Source & Location \\
\hline Azotobacter chroococcum 1 & $\begin{array}{c}\text { Bean rhizosphere } \\
\text { ( Phaseolus vulgaris ) }\end{array}$ & $\begin{array}{c}\text { Field in Al-Tweeth town / south east } \\
\text { of Baghdad }\end{array}$ \\
\hline Azotobacter chroococcum 2 & Garden soil & Al-Zafarania city / Baghdad \\
\hline Bacillus sp. & $\begin{array}{c}\text { Okra rhizosphere } \\
\text { ( Hibiscus esculentus ) }\end{array}$ & $=$ \\
\hline Bacillus subtilis & $\begin{array}{l}\text { Ministryof Agriculture/ } \\
\text { Organic Culture Center }\end{array}$ & \\
\hline $\begin{array}{c}\text { Bacillus pumilus } \\
\text { Pseudomonas fluorescence }\end{array}$ & $\begin{array}{l}=\quad=\quad= \\
=\quad=\quad=\end{array}$ & \\
\hline
\end{tabular}

Fungal pathogen ( $R$. solani )

One isolate of fungal pathogen $R$. solani was obtained from Department of Biocontrol for Plant Diseases at Agricultural Researcher Office/ Ministry of Science and Technology was used in this study.

\section{Bacterial antagonistic activity evaluation}

The method described by [10] was used to determine antagonistic activity of the six strains of plant growth promoting bacteria Azotobacte rchroococcum1, Azotobacter chroococcum2, Bacillus sp., Bacillus subtilis, Bacillus pumilus and Pseudomonas fluorescence against fungal pathogen R.solani. One $5 \mathrm{~mm}$ disk of pure culture of the pathogen was placed at the center of Petri dish $10 \mathrm{~cm}$ diameter containing PSA potato sucrose agar media. Circular line, made of a $5 \mathrm{~cm}$ diameter Petri dish dipped in a bacterial suspension of one of the six strains of bacteria was placed surrounding the fungal pathogen. Plates were incubated for $72 \mathrm{hr}$. at $25^{\circ} \mathrm{c}$ and growth diameter of the pathogen was measured and compared to control growth, where the bacterial suspension was replaced by sterile distilled water.

Results were expressed as the means of the percentage of the growth inhibition in the presence of any of the bacterial strains.

Inhibition percentage was calculated using the following formula:

\section{Greenhouse experiment}

$$
\text { \%Inhibition }=[1-\text { fungal growth } / \text { control growth }] \times 100[11]
$$

The experiment was carried out in greenhouse at Department of Biocontrol for Plant Diseases/Agricultural and Food Technology Researches Center in Al-Zafrania City from 22/3/20114/7/2011 to evaluated the interaction between six strains of plant growth promoting bacteria and the pathogen $R$. solani for their potential to stimulate eggplant resistance against root rot disease. One isolate from the pathogen was used as causal agent of eggplant root rot disease at rate of $1 \mathrm{ml}$ of fungal suspension 105spore/ml of the 7 days old culture on PSA Potato sucrose agar medium per $1 \mathrm{ml}$ of soil before planting. Eggplant seeds were soaked in bacterial suspension $10^{8} \mathrm{CFU} / \mathrm{ml}$ for $10 \mathrm{~min}$ and air 
dried before seeded at rate of 5 seeds/ pot. Eggplant seeds were sown in trays $30,50,10 \mathrm{~cm}$ deep containing autoclave coarse clay sand 1:1 v/v and watered twice a week. After 20 days, similar healthy seedlings $10 \mathrm{~cm}$ length were uprooted and treated with bacterial suspension of the six strains $106 \mathrm{CFU} /$ $\mathrm{ml}$ and planted in holes at rate 2 seedlings/ hole. Treatments were distributed in greenhouse according to Randomized Complete Blocks Design RCBD in three replicates each replicate 10 plants to evaluate the following treatments:

1- Control.

2- Pathogen only.

3- Azotobactre chroococcum 1+ pathogen.

4- Azotobactre chroococcum $2+$ pathogen.

5- Bacillus sp. + pathogen.

6- Bacillus subtilis + pathogen.

7- Bacillus pumilus + pathogen.

8- Pseudomonas fluorescence + pathogen.

Plants were harvested at the end of the experiment, growth parameters were recorded beside disease incidence and severity as following:

1-Mean length of shoot and root of plants.

2-Fresh and dry weight of plants.

3-Seeds germination and the first day of germination.

4-Fruits weight and plant productivity.

5-Disease incidence and severity.

\section{Results and Discussion}

Antagonistic activity of bacterial strains against $R$. solani

The results showed that the tested strains varied in their ability in reducing radial growth rate of the pathogen and the percentage of pathogen growth inhibition Table (2). Bacillus subtilis strain showed significant reduction in radial growth of $R$. solani $24.66 \mathrm{~mm}$ as compared to other strains $A$. chroococcum 1 , A. chroococcum 2 and Bacillus sp. Which were recorded $37.66,40.33,35.33 \mathrm{~mm}$ respectively. Also B. subtilis appeared significant increment in percentage of pathogen growth inhibition $46.26 \%$ as compared to A. chroococcum 1 , A. chroococcum 2 and Bacillus sp. 17.96, $12.16,23.06 \%$ respectively. These results are due to the antagonistic metabolites secreted by bacterial strains and suggests that the mode of action exerted and the type of antifungal metabolites produced by the six strains was varied. Reduction of fungal growth of $R$. solani and formation of inhibition zones were presumably due to the antifungal substances and/ or cell wall degrading enzymes released by bacterial strains into the culture media $[12,13,14]$.

Table (2): Antagonistic Activity of Bacterial Isolates against $R$. solani

\begin{tabular}{ccc}
\hline Bacterial isolate & \multicolumn{2}{c}{$R$. solani } \\
\cline { 2 - 3 } & Radial growth rate $(\mathrm{mm})$ & \% Inhibition \\
\hline A. chroococcum 1 & 37.66 & $\mathbf{1 7 . 9 6}$ \\
A. chroococcum 2 & 40.33 & $\mathbf{1 2 . 1 6}$ \\
Bacillus sp. & 35.33 & $\mathbf{2 3 . 0 6}$ \\
B. subtilis & 24.66 & $\mathbf{4 6 . 2 6}$ \\
B. pumilus & 27.66 & 39.83 \\
P. fluorescence & 30.66 & 28.36 \\
Control & 46.0 & - \\
LSD $(\mathrm{P}=0.05)$ & 1.75 & 5.05 \\
\hline
\end{tabular}

Treatment of eggplant seeds with bacterial suspension of PGPB strains and their effect on some eggplant growth parameters under greenhouse conditions

Treatment of eggplant seeds with PGPB strains showed that all the strains significantly increased seeds germination, B. subtilis showed $92.16 \%$ as compared to control treatment $69.56 \%$ Table (3). Also, the results revealed that most of bacterial strains significantly increased eggplant growth parameters shoot and root length, fresh and dry weight of plant, fruit weight, and plant productivity Tables $(4,5) . B$. subtilis was the superior which recorded 93.83,26.5 cm , 589.3,163.03g/ plant, 101.63g, 1180.0)g/ plant respectively as compared to both positive and negative control treatment which recorded 78.33, 
$47.66 \mathrm{~cm}, 16.5,12.83 \mathrm{~cm}, 305.3,148.3 \mathrm{~g} /$ plant, 88.03, 39.46g/ plant, 62.63, 34.43g , 642.33, 141.0g/ plant respectively.

Table (3): Treatment of Eggplant Seeds with Bacterial Suspension and Their Effect on Seed Germination under Greenhouse Conditions

\begin{tabular}{ccc}
\hline Treatment & \%Seed germination & $\mathbf{1}^{\text {st }}$ Germination \\
\hline A. chroococcum 1 & 80.16 & 12 \\
A. chroococcum 2 & 82.16 & 12 \\
Bacillus $s p$. & 71.50 & 11 \\
C. subtilis & 92.16 & 12 \\
A. pumilus & 84.83 & 14 \\
P. fluorescence & 89.66 & 15 \\
Control & 69.56 & - \\
\hline LSD $(\mathrm{P}=0.05)$ & 1.50 & 14 \\
\hline
\end{tabular}

Table (4): Treatment of Eggplant Seeds and Seedlings With Bacterial Suspension and Their Effect on Some Plant Growth Parameters Infected by R. solani Under Greenhouse Conditions

\begin{tabular}{|c|c|c|c|c|}
\hline Treatment & $\begin{array}{l}\text { Shoot length } \\
\text { cm }\end{array}$ & $\begin{array}{l}\text { Root length } \\
\text { cm }\end{array}$ & $\begin{array}{c}\text { Fresh plant weight } \\
\text { (g/plant) }\end{array}$ & $\begin{array}{l}\text { Dry plant weight } \\
\text { (g/plant) }\end{array}$ \\
\hline Control & 78.33 & 16.5 & 305.3 & 88.03 \\
\hline Pathogen only & 47.66 & 12.83 & 148.3 & 39.46 \\
\hline A.chro. 1+Path. & 88.56 & 22.83 & 530.6 & 127.5 \\
\hline A. chro.2+Path. & 83.40 & 21.5 & 520.3 & 120.4 \\
\hline Bacillus sp. +Path. & 82.50 & 19.5 & 529.16 & 124.4 \\
\hline B.subtilis+Path. & 93.83 & 26.5 & 589.3 & 163.03 \\
\hline B.pumilus+Path. & 91.50 & 20.5 & 566.30 & 141.4 \\
\hline P. fluorescence+Path. & 87.46 & 24.16 & 561.13 & 144.1 \\
\hline $\operatorname{LSD}(P=0.05)$ & 2.07 & 1.14 & 1.88 & 1.46 \\
\hline
\end{tabular}

The results of Table (4) revealed that $B$. subtilis + pathogen treatment was the best in increment all the tested growth parameters (shoot and root length, fresh and dry weight of plant which recorded 93.83,26.5cm, 589.3,163.03/ plant respectively as compared to control treatment $78.33,16.5 \mathrm{~cm}$, $305.3,88.03 \mathrm{~g} /$ plant respectively. Also the results showed that $B$. subtilis recorded significant increment in fruits weight and plant productivity Table (5) which recorded $101.63 \mathrm{~g}, 1180.0 \mathrm{~g} /$ plant while, in control treatment $62.63 \mathrm{~g}, 642.33 \mathrm{~g} /$ plant respectively.

Plant growth promoting bacteria produced a variety of growth promoting substances like IAA, gibberellins, vitamins $[15,16]$ and antifungal substances $[17,18,19,14]$, so it improved seeds germination and increased plant growth parameters. The results obtained from Tables $[17,18,20]$ may be to beneficial effects of bacterial strains on growth and eggplant seeds germination in multiple ways, which include, ability to produce vitamins and growth promoting substances that enhance seeds germination end eggplant growth.

Table (5): Rate of fruits weight and plant productivity of Eggplant plants under greenhouse conditions

\begin{tabular}{ccc}
\hline Treatment & Fruit weight $(\mathrm{g})$ & Plant productivity g/ plant \\
\hline Control & 62.63 & $\mathbf{6 4 2 . 3 3}$ \\
Pathogen only & 34.43 & 141.0 \\
A.chro. 1+Path. & 69.76 & $\mathbf{7 3 9 . 6 6}$ \\
A. chro.2+Path. & 71.96 & $\mathbf{7 4 3 . 6 6}$ \\
Bacillus sp. +Path. & 64.83 & 675.73 \\
B.subtilis+Path. & 101.63 & $\mathbf{1 1 8 0 . 0}$ \\
B.pumilus+Path. & $\mathbf{8 8 . 2 3}$ & $\mathbf{1 0 4 5 . 0}$ \\
P. fluorescence+Path. & $\mathbf{8 6 . 4 3}$ & $\mathbf{8 8 9 . 6 6}$ \\
LSD $(\mathrm{P}=\mathbf{0 . 0 5}$ ) & 3.48 & 3.71 \\
\hline
\end{tabular}

Results of Table (6) showed that all the tested treatment significantly decreased the disease incidence and severity of eggplant infected by the pathogen under greenhouse conditions as compared to both negative and positive control treatment. $B$. subtilis +pathogen treatment was the best which recorded $46.30 \%, 0.23$ respectively as compared to control treatment $4.4,77.33 \%, 0.07,0.71$ respectively. 
Table (6): Disease incidence and severity of eggplant plants infected by $R$. solani under greenhouse conditions.

\begin{tabular}{ccc}
\hline Treatment & Disease incidence \% & Disease severity \\
\hline Control & 4.4 & 0.07 \\
Pathogen only & 77.33 & 0.71 \\
A.chro. 1+Path. & 51.93 & 0.35 \\
A. chro.2+Path. & 47.33 & 0.33 \\
Bacillus sp. +Path. & 46.30 & 0.29 \\
B.subtilis+Path. & 34.06 & 0.23 \\
B.pumilus+Path. & 38.16 & 0.28 \\
P. fluorescence+Path. & 41.33 & 0.30 \\
LSD $(\mathrm{P}=0.05$ ) & 2.26 & 0.04
\end{tabular}

PGPB can affect plant growth in two general ways, either directly or indirectly [20, 21]. Indirect promoting occurs when PGPB lessen or prevent the harmful effects of one or more deleterious microorganisms. This is chiefly attained through biocontrol, or the antagonisms of soil pathogens. Specifically, colonization or the biosyntheses of antibiotics and other secondary metabolites can prevent pathogen invasion and establishment. Direct promoting of plant growth by PGPB occurs when the plant is supplied with a compound that is synthesized by the bacteria, or when PGPB otherwise facilities plant uptake of soil nutrients, possibilities include nitrogen fixation, siderophore synthesis, phytohormone synthesis, and solubilization of minerals to make them available for plant uptake and use [20].

\section{References}

1. Gupta, S K. and Third, T S. (2006). Disease problems in vegetable production. In: Disease of eggplant. Scientific Publishers - India. 409-429.

2. Dursun, A., Ekinci, M. and Domez, M F. (2010). Effects of foliar application of plant growth promoting bacteria on chemical contents, yield and growth of tomato (Lycopersiconesculentum L.) and cucumber (Cucumissativus L.). Pak. J. Bot. 42(5): 3349-3356.

3. Esitken, A., Pirlak, L., Turan, M. and Sahin, F. (2006). Effects of foliar application of Bacillus subtilis on the yield, growth and control of shot-hole disease (Coryneum blight) of apricot, Gartenbauwissenschaft. 67: 139-142.

4. Fatima, F., Saleemi, M., Zia, M., Sultani, T., Aslam, M., Rehman, R. and Chaudhary, M F. (2009). Antifungal activity of plant growth promoting rhizobacteria isolates against Rhizoctoniasolani in wheat. Afri. J. Biotechnol. 8(2): 219-225.

5. Gholami, A., Shahsavani, S., and Nezarat, S. (2009). The effect of plant growth promoting rhizobacteria (PGPR) on germination, seedling growth and yield of maize. World Acad. Sci. Eng. \& Technol. 49:19-25.

6. Narula, N., Remus, R., Deubel, A., Dudeja, S. and Bell, R. (2007). Comparison of the effectiveness of wheat roots colonization by Azotobacter chroococcum and Pantoeaagglomerans using serological techniques. Plant Soil Environ. 53 (4): 167- 176.

7. Siddiqui, I A. (2001). Effect of microbial antagonists on in vitro growth of Pythium aphanidermatum . J. Biol. Sci. 1(4):224-226.

8. Al-Azawy, A Q. (2010). Efficiency of interaction between Azotobacter sp. and arbuscular mycorrhizal fungi for their potential to stimulate tomato plant resistance to root rot disease. Ph.D. Thesis. Baghdad University/ College of Science.

9. Kamal, A M., Hashem, A. and Mohamed, M. (2009). Biological control of Fusarium wilts in tomato by yeasts and rhizobacteria. Plant Pathol. J. 25:199-204.

10. Montealegre, J R., Reyes, R., Perez, LM., Herrera, R., Silva, P. and Besoain, X. (2003). Selection of bioantagonistic bacteria to be used in biological control of Rhizoctonia solani in tomato. Electron J. Biotechnol. 6(2): 115-127.

11. Mojica-Marin, V., Luna -Olvera, H A., Sandoval-Coronado, C F., Pereyra - Alferez, B., Morales-Ramos, L H., Hernandez-Luna, C E. and Alvarado-Gomez, O G. (2008). Antagonistic activity of selected strains of Bacillus thuringinsis against Rhizoctonia solani of chili pepper. Afric. J. Biotechnol. 7(9): 1271-1276.

12. Mali, G V. and Bodhanker, M G. (2009). Antifungal and phytohormone production potential of Azotobacter chroococcum isolates from Graundnut (Arachis hypogeal L.) rhizosphere. Asian J. Exper. Sci. 23 (1): 293-297.

13. Verma, S., Kumar, V., Narula, N. and Merbach, W. (2001 b). Studies on in vitro production of antimicrobial substances by Azotobacter chroococcum isolates/ mutants. (Abstract). 
14. Todorova, S. and Kozhuharom, L. (2010). Characteristics and antimicrobial activity of Bacillus subtilis strains isolates from soil. World J. Microbiol \& Biotechnol. 26:1207-1216.

15. Verma, S., Kukreja, K., Pathak, D V., Suneja, S. and Narula, N. (2001a) In vitro production of plant growth regulators by Azotobacter chroococcum. Ind. J. Microbiol. 41 (4): 305 - 307.

16. Ahmed, F., Ahmed, I. and Khan, M S. (2005). Indole acetic acid production by the indigenous isolates of Azotobacter and Florescent Pseudomonas in the presence and absence of tryptophan. Turk. J. Biol. 29: 29 - 34.

17. Cartwright, D K., Chilton, WS. and Benson, DM. (1995). Pyrrolnitrin and phenazine production by Pseudomonas cepacia, strain 5.5B, a biocontrol agent of Rhizoctonia solani. Appl. Microbiol. Biotechnol. 43:211-216.

18. Cartwright, D K. and Benson, D M. (1995). Comparison of Pseudomonas species and application techniques for biocontrol of Rhizoctonia stem rot Poinsettia. Plant Disease. 79(3): 309-313.

19. Ramyasruthi, S., Pallavi, O., Pallavi, S., Tilak, K. and Srividya, S. (2012). Chitinolytic and secondary metabolite producing Pseudomonas fluorescence isolated from solanaceae rhizosphere effective against broad spectrum fungal phytopathogns. Asian J. Plant Sci. \& Res. 2(1): 16-24.

20. Barea, J., Pozo, M J., Azcon, R. and Azcon - Aguilar, C. (2005). Microbial co-operation in the rhizosphere. J. Exp. Bot. 56:1761-1778.

21. Compant, S., Duffy, B., Nowak, J., Clement, C. and Barka, E A. (2005). Use of plant growth promoting bacteria for biocontrol of plant diseases: principles, mechanisms of action, and future prospects. Appl. \&Environ. Microbiol. 71:4951-4959. 